\title{
PENGARUH BAURAN PEMASARAN TERHADAP KEPUTUSAN KONSUMEN PERUSAHAAN JASA PENGIRIMAN PAKET PADA PT JNE AGEN 012 CITEUREUP KABUPATEN BOGOR
}

\section{THE EFFECT OF MARKETING MIX ON CUSTOMER DECISION AT "PT JNE AGEN 012 CITEUREUP BOGOR"}

\author{
Lucky Hikmat Maulana ${ }^{1)}$; Eka Rahayu ${ }^{2)}$ \\ Program Studi Manajemen Fakultas Ekonomi Universitas Djuanda Bogor \\ Email: lucky.hikmat.m@unida.ac.id; erahayu62@gmail.com
}

\begin{abstract}
This study aims to determine the effect of the marketing mix on customer decisions of package delivery service companies at PT JNE Agen 012 Citeureup Bogor regency both simultaneously and partially. Questionnaires were distributed to 100 customers who were sampled. Validity and reliability test results show that all question are valid and reliable. Based on the results of the recapitulation of customers responses to the marketing mix the product $\left(X_{1}\right)$ is very good, price $\left(X_{2}\right)$ is very good, location $\left(X_{3}\right)$ is very good, promotion $\left(X_{4}\right)$ is very good, people $\left(X_{5}\right)$ are very good, process $\left(X_{6}\right)$ is good, customer service $\left(X_{7}\right)$ is very good. The result of correlation coefficient analysis states that there is a very strong influence between marketing mix and customer decision, from the result of coefficient of determination can be explained by $86,2 \%$ by the marketing mix and 13,8\% influenced by other variable not examined in this study, such as physical evidence. The multiple regression analysis of the $F$ test (simultaneous) and t test (partial) states that the marketing mix has a positive and significant effect on the customer decisions of the package delivery service companies in PT JNE Agen 012 Citeureup Bogor.
\end{abstract}

Keywords : customer decision, customer responses, marketing mix

\begin{abstract}
ABSTRAK
Penelitian ini untuk dapat mengetahui pengaruh mengenai bauran pemasaran terhadap keputusan konsumen perusahaan jasa pengiriman paket pada PT JNE Agen 012 Citeureup Kabupaten Bogor baik secara simultan maupun parsial. Kuesioner didistribusikan kepada 100 konsumen yang dijadikan sampel. Hasil uji pada validitas serta reliabilitas menunjukkan bahwa seluruh butir pertanyaan dinyatakan valid dan reliabel. Berdasarkan hasil rekapitulasi tanggapan konsumen terhadap bauran pemasaran yaitu produk $\left(\mathrm{X}_{1}\right)$ sangat baik, harga $\left(\mathrm{X}_{2}\right)$ sangat baik, lokasi $\left(\mathrm{X}_{3}\right)$ sangat baik, promosi $\left(\mathrm{X}_{4}\right)$ sangat baik, orang $\left(\mathrm{X}_{5}\right)$ sangat baik, proses $\left(\mathrm{X}_{6}\right)$ baik, layanan pelanggan $\left(\mathrm{X}_{7}\right)$ sangat baik. Hasil analisis koefisian korelasi memberikan pengaruh yang sangat kuat antara bauran pemasaran dan keputusan konsumen, dari hasil koefisien determinasi dapat dijelaskan sebesar 86,2\% oleh bauran pemasaran dan 13,8\% dipengaruhi oleh variabel lain yang tidak diteliti dalam penelitian ini, seperti physical evidence. Adapun analisis regresi berganda dari uji $\mathrm{F}$ (simultan) dan uji t (parsial) menyatakan bahwa bauran pemasaran berpengaruh positif serta signifikan terhadap keputusan konsumen perusahaan jasa pengiriman paket pada PT JNE Agen 012 Citeureup Kabupaten Bogor.
\end{abstract}

Kata kunci : bauran pemasaran, keputusan konsumen, tanggapan konsumen 


\section{PENDAHULUAN}

Perkembangan zaman membuat manusia ingin lebih diperhatikan, sehingga perusahaan perlu mengembangkan bisnisnya. Begitu juga persaingan dibidang jasa, khususnya pengiriman paket (ekspedisi), kebutuhan tersebut ialah kebutuhan hidup yang menunjang mobilitas masyarakat global saat ini, sehingga perusahaan perlu memperhatikan perubahan minat dan kebutuhan konsumen, kemudian pemenuhan tuntutan konsumen dapat terwujud dengan optimalisasi pelayanannya.

Kenaikan tuntutan jasa layanan ekspedisi perlu diikuti bersama keprofesionalan dalam mengelolanya. Perkembangan tersebut dipengaruhi oleh berbagai tuntutan dari lingkungan eksternal antara lain para stakeholder yang mengharapkan pelayanan prima dan berakhir pada keputusan pembelian, kemudian tuntutan dari pihak internal yaitu pengendalian biaya. Pengendalian biaya merupakan masalah yang pelik karena melibatkan beberapa pihak yaitu mekanisme pasar, perilaku ekonomis dan tenaga kerja profesional.

Bauran pemasaran berfungsi untuk pemenuhan tuntutan pelayanan ekspedisi. Undang-undang No. 38 Tahun 2009 tentang Pos menjelaskan bahwa perusahaan kini dapat dengan mudah masuk dalam usaha jasa bidang kurir, pemilihaan perusahaan menjadi luas tidak hanya Badan Usaha Milik Negara tetapi Badan Usaha Milik Daerah maupun koperasi dan swasta bisa ikut menjalankan usaha kurir. Dengan munculnya peraturan tersebut, jasa ekspedisi saat ini mulai beragam, selaras dengan semakin maraknya bisnis daring (dalam jaringan) atau e-commerce. Pertumbuhan ecommerce tersebut menjadi market segment yang besar bagi perusahaan ekspedisi dan logistik, mengingat perdagangan elektronik memerlukan jasa kurir dalam pengiriman barang dagangannya.

PT JNE adalah satu diantara beberapa pilihan masyarakat untuk mengirimkan berbagai barang jenis paket. Harga yang ditawarkan JNE cenderung lebih murah dan gerai yang dimiliki JNE terdapat dibeberapa lokasi yang mudah diakses dan seringkali buka di hari libur dikarenakan gerainya merupakan milik pribadi. Salah satu JNE di wilayah Citeureup adalah PT JNE agen 012. Luasnya jasa pengiriman paket di Indonesia salah satunya dapat digambarkan pada tabel 1, berikut terdapat beberapa perusahaan jasa kurir Top Brand Award tahun 2015 - 2016 :

Tabel 1. Top Brand Award Tahun 2015 - 2016

\begin{tabular}{lcc}
\hline \multirow{2}{*}{ Merek } & \multicolumn{2}{c}{ Tahun } \\
\cline { 2 - 3 } & 2015 & 2016 \\
\hline JNE & $43.5 \%$ & $47.6 \%$ \\
Tiki & $36.2 \%$ & $35.7 \%$ \\
Pos Indonesia & $6.7 \%$ & $9.6 \%$ \\
DHL & $2.1 \%$ & $1.3 \%$ \\
\hline
\end{tabular}

Sumber : www.topbrand-award.com

Dapat diketahui pada tabel 1 JNE mendapatkan persentase tertinggi selama dua tahun berturut-turut dengan persentase terakhir sebesar $47,6 \%$, pada urutan kedua terdapat tiki kemudian pos indonesia mendapat urutan ketiga dan untuk yang terakhir terdapat DHL. Akan tetapi meskipun JNE menjadi top brand selama dua tahun berturut-turut PT JNE agen 012
Citeureup pada tahun terakhir mengalami penurunan ketercapaian target, yang mungkin hal tersebut dikarenakan kurang optimalnya kegiatan bauran pemasaran, berikut data pengiriman paket PT JNE agen 012 Citeureup pada tahun 2016: 
Tabel 2. Target dan Realisasi Pengiriman Paket Tahun 2016 JNE Agen 012 Citeureup Kabupaten Bogor

\begin{tabular}{lccc}
\hline \multicolumn{1}{c}{ Bulan } & Target & Realisasi & Ketercapaian target $(\%)$ \\
\hline Januari & 1.200 & 1.321 & 110 \\
Februari & 1.200 & 1.210 & 101 \\
Maret & 1.200 & 987 & 82 \\
April & 1.200 & 966 & 81 \\
Mei & 1.200 & 905 & 75 \\
Juni & 1.200 & 1.073 & 89 \\
Juli & 1.200 & 1.247 & 104 \\
Agustus & 1.200 & 1.384 & 115 \\
September & 1.200 & 1.308 & 109 \\
Oktober & 1.200 & 1.007 & 84 \\
November & 1.200 & 1.162 & 97 \\
Desember & 1.200 & 1.321 & 110 \\
\hline Rata-rata & 1.200 & 1.158 & 96 \\
\hline
\end{tabular}

Sumber : JNE Agen 012 Citeureup Kabupaten Bogor

Dari tabel 2 dapat dijabarkan bahwa ketercapaian target memang berfluktuasi seperti terlihat dalam 1 (satu) tahun terdapat rata-rata sejumlah 1.158 pengunjung atau 96\%. Bulan Agustus merupakan pencapaian tertinggi dengan jumlah pengunjung melebihi target yaitu 1.384 pengunjung atau $115 \%$ sedangakan pengunjung terendah pada bulan Mei dengan jumlah 905 pengunjung atau $75 \%$. Hal tersebut dapat lebih dioptimalkan untuk mencapai tujuan akhir yang telah ditetapkan, melalui perumusan bauran pemasaran dimana hal-hal yang telah dijelaskan tersebut diharapkan dapat dengan mudah membantu pencapaian perusahaan yakni menambah perolehan laba ketercapaian target jumlah pengguna jasa ekspedisi, sehingga perusahaan perlu mengetahui hal-hal yang mampu memberikan pengaruh terhadap keputusan penggunaan jasa.

Menurut Purnomohadi, Eri dalam Sumarwan, dkk (2012:199), pengambilan keputusan konsumen merupakan salah satu aspek yang penting di dalam pemasaran karena konsumen akan melakukan pembelian atau tidak melakukan pembelian berdasarkan keputusan yang mereka tetapkan.

Maka berdasarkan latar belakang masalah, peneliti mangangkat kondisi tersebut dalam suatu penelitian dengan judul "Pengaruh Bauran Pemasaran Terhadap Keputusan Konsumen Perusahaan Jasa
Pengiriman Paket Pada PT JNE Agen 012 Citeureup Kabupaten Bogor"

\section{MATERI DAN METODE}

Suatu perusahaan tidak dapat bertahan apabila tidak dapat memasarkan jasa atau produk yang dihasilkan. Menurut Alma (2014:130), manajemen pemasaran merupakan proses untuk meningkatkan efisiensi dan efektivitas dan kegiatan pemasaran yang dilakukan oleh individu atau oleh perusahaan.

\section{Bauran Pemasaran}

Menurut Lupiyoadi (2014:92), bauran pemasaran (marketing mix), merupakan perangkat atau alat bagi pemasar yang terdiri atas berbagai unsur suatu program pemasaran yang perlu dipertimbangkan agar implementasi strategi pemasaran dan penentuan posisi yang ditetapkan dapat berjalan sukses. Unsur marketing dikenal dengan 4P (product, price, place, promotion) sedangkan untuk jasa perlu penambahan 3P, sehingga menjadi $7 \mathrm{P}$ yaitu, produk (product), harga (price), lokasi (place), promosi (promotion), orang (people), proses (process), dan layanan pelanggan (customer service). Berdasarkan beberapa pernyataan tersebut dapat dijelaskan bahwa, bauran pemasaran merupakan sekumpulan program pemasaran yang dimanfaatkan untuk memenuhi target 
perusahaan dalam pencapaian tujuan pemasar dalam pemenuhan target pasarnya.

\section{Keputusan Pembelian}

Abdullah dan Tantri (2016:123), menjelaskan bahwa para pemasar harus mendalami berbagai pengaruh terhadap pembeli dan mengembangkan pemahaman mengenai bagaimana sebenarnya para konsumen membuat keputusan pembelian mereka. Menurut Tjiptono (2016:60), keputusan pengguna jasa atau biasa disebut dengan keputusan pembelian adalah sebuah proses dimana konsumen mengenal masalahnya, mencari informasi mengenai produk atau merek tertentu dan mengevaluasi seberapa baik masing-masing alternatif tersebut dapat memecahkan masalahnya, yang kemudian mengarah pada keputusan pembelian. Pengertian tersebut memberikan kesimpulan bahwa perilaku keputusan pembelian mengacu pada keputusan konsumen.

\section{Hubungan Bauran Pemasaran dengan Keputusan Konsumen}

Menurut Tjiptono (2014:41) bauran pemasaran merupakan seperangkat alat yang dapat digunakan pemasar untuk membentuk karakteristik jasa yang ditawarkan kepada pelanggan. Berdasarkan teori tersebut dapat diartikan bahwa bauran memiliki pengaruh terhadap keputusan konsumen. paradigma penelitian berikut ini :

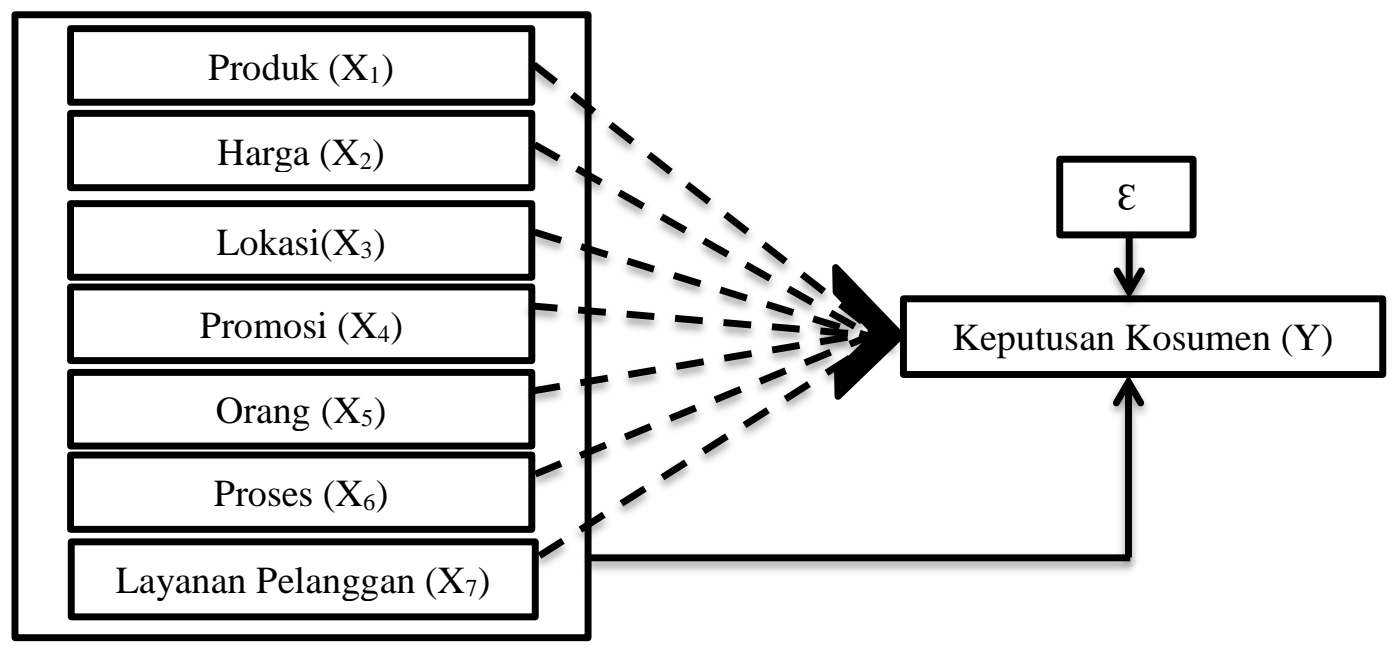

Keterangan:

\section{Gambar 1. Paradigma Penelitian}

$-\rightarrow=$ Pengaruh Parsial

$\longrightarrow=$ Pengaruh Simultan

\section{Objek dan Lokasi Penelitian}

Objek yang diteliti adalah perusahaan jasa ekspedisi PT JNE Agen 012 Citeureup Kabupaten Bogor. Lokasi penelitian yaitu JNE Agen 012 Citeureup, yang beralamat di Jalan Raya Mayor Oking Jaya Atmaja, Kec. Citeureup - Kab. Bogor.

\section{Desain Penelitian}

Penelitian dengan desain yang dipergunakan adalah deskriptif dan verifikatif dengan pendekatan kuantitatif. Dalam penelitian ini pengolahan data menggunakan software IBM SPSS 20 for windows.

\section{Operasionalisasi Variabel}

Adapun operasional variabel pada penelitian ini, dapat dijelaskan pada tabel berikut : 
Uji pendahuluan diawali dengan memberikan kuesioner yang berisikan pernyataan mengenai variabel bauran pemasaran dan keputusan konsumen kepada responden. Hasil jawaban responden kemudian diuji validitas terlebih dahulu kemudian dilanjutkan pada uji reliabilitas. Dalam hal ini variabel bauran pemasaran (X) diukur dengan 15 item pertanyaan dan variabel keputusan konsumen (Y) diukur dengan 5 item pertanyaan. Hasil uji validitas menyatakan bahwa untuk seluruh pertanyaan dinyatakan valid karena memiliki nilai $r_{\text {hitung }}$ $\geq 0,30$ sehingga

item pernyataan bauran pemasaran dan keputusan konsumen dinyatakan valid. Setelah alat ukur dinyatakan valid, maka alat tersebut diuji reliabilitanya. Setiap variabel memiliki nilai Cronbach Alpha $\geq 0,6$. Dengan nilai ini berarti bahwa setiap variabel X (produk, harga, promosi, lokasi, orang, proses, layanan pelanggan) dan $\mathrm{Y}$ (keputusan konsumen) dapat dinyatakan reliabilitas (keandalan) diterima. Uji yang digunakan dalam asumsi klasik, antara lain : uji Normalitas, uji multikolinearitas, dan uji heteroskedastisitas. Jika regresi memenuhi asumsi tersebut maka merupakan regresi yang baik.

\section{Metode Analisis Data}

Untuk mengukur pengaruh antara variabel terikat dengan 2 (dua) maupun lebih dengan variabel bebas persamaan dalam regresi berganda, digunakan rumus sebagai berikut untuk menghitung regresi berganda:

$$
\begin{aligned}
\mathrm{Y} & =\mathrm{a}+\beta_{1} \mathrm{X}_{1}+\beta_{2} \mathrm{X}_{2}+\beta_{3} \mathrm{X}_{3}+\beta_{4} \mathrm{X}_{4}+ \\
\beta_{5} \mathrm{X}_{5}+\beta_{6} \mathrm{X}_{6}+\beta_{7} \mathrm{X}_{7}+\varepsilon & \\
\text { Keterangan : } & \\
\mathrm{Y}= & \text { Variabel dependen keputusan } \\
& \text { konsumen } \\
\mathrm{a}= & \text { Bilangan konstanta } \\
\mathrm{X}_{1}= & \text { Produk } \\
\mathrm{X}_{2}= & \text { Harga } \\
\mathrm{X}_{3}= & \text { Lokasi } \\
\mathrm{X}_{4}= & \text { Promosi } \\
\mathrm{X}_{5}= & \text { Orang } \\
\mathrm{X}_{6}= & \text { Proses } \\
\mathrm{X}_{7}= & \text { Layanan pelanggan } \\
\beta_{1}= & \text { Koefisien regresi variabel produk } \\
\beta_{2}= & \text { Koefisien regresi variabel harga } \\
\beta_{3}= & \text { Koefisien regresi variabel lokasi } \\
\beta_{4}= & \text { Koefisien regresi variabel promosi } \\
\beta_{5}= & \text { Koefisien regresi variabel orang } \\
\beta_{6}= & \text { Koefisien regresi variabel proses } \\
\beta_{7}= & \text { Koefisien regresi variabel layanan } \\
\varepsilon & \text { pelanggan } \\
\varepsilon= & \text { Pengaruh error lain yang tidak } \\
& \text { diteliti }
\end{aligned}
$$

Analisis Korelasi Ganda (multiple correlation) adalah nilai angka yang menunjukkan arah dan kuatnya dua variabel independen tersebut memiliki hubungan yang kuat secara bersamaan maupun lebih dengan satu variabel dependen.

Tabel 4. Interprestasi Koefisien Korelasi

\begin{tabular}{cc}
\hline Interval Koefisien & Tingkat Hubungan \\
\hline $0,00-0,199$ & Sangat Rendah \\
$0,20-0,399$ & Rendah \\
$0,40-0,599$ & Sedang \\
$0,60-0,799$ & Kuat \\
$0,80-1,000$ & Sangat Kuat
\end{tabular}

Sumber : Sugiyono (2017:231)

Dalam penelitian ini untuk mengetahui jumlah prosentase pada perubahan variabel yang terikat, disebabkan dari variabel yang bebas dapat menggunakan koefisien

determinasi. Jika $\mathrm{R}^{2}$ nilainya menjasi semakin besar, maka jumlah prosentase perubahan dengan variabel terikat yang 
disebabkan dari variabel bebas semakin tinggi begitupun sebaliknya.

Untuk mengetahui pengaruh variabel bebas terhadap variabel terikat secara simultan dapat menggunakan uji $\mathrm{F}$ dengan kriteria pengujian sebagai berikut:

1) Apabila $F_{\text {hitung }}$ lebih kecil atau sama dengan $F_{\text {tabel }}\left(F_{\text {hitung }} \leq F_{\text {tabel }}\right)$ pada $\alpha=$ 0,05, maka Ho diterima dan $\mathrm{Ha}$ ditolak artinya secara simultan variabel bauran pemasran tidak berpengaruh terhadap variabel keputusan konsumen.

2) Apabila Fhitung lebih besar dari nilai $\mathrm{F}_{\text {tabel }}\left(\mathrm{F}_{\text {hitung }}>\mathrm{F}_{\text {tabel }}\right)$ pada $\alpha=0,05$, maka Ho ditolak dan Ha diterima, artinya secara simultan variabel bauran pemasaran berpengaruh terhadap keputusan konsumen.

Untuk mengetahui pengaruh secara parsial variabel bebas terhadap variabel terikat dapat menggunakan uji $\mathrm{t}$ dengan kriteria pengujian sebagai berikut :

1) Apabila thitung lebih kecil atau sama dengan $t_{\text {tabel }}\left(t_{\text {hitung }} \leq t_{\text {tabel }}\right)$, maka Ho diterima dan $\mathrm{Ha}$ ditolak artinya secara parsial variabel bauran pemasran tidak berpengaruh terhadap variabel keputusan pembelian.

2) Apabila thitung lebih besar atau sama dengan $t_{\text {tabel }}\left(t_{\text {hitung }}>t_{\text {tabel }}\right)$, maka Ho ditolak dan $\mathrm{Ha}$ diterima, artinya secara parsial variabel bauran pemasaran berpengaruh terhadap keputusan pembelian.

\section{HASIL DAN PEMBAHASAN}

Penelitian ini penulis menggunakan kuesioner untuk mengetahui kondisi bauran pemasaran PT JNE Agen 012 Citeureup Kabupaten Bogor. pada penelitian ini jumlah konsumen yang dijadikan sampel adalah 100 orang. Sehingga gambaran umum konsumen pengguna jasa ekspedisi PT JNE Agen 012 Citeureup Kabupaten Bogor dapat dijelaskan dan diuraikan sebagai berikut : konsumen JNE rata-rata berjenis kelamin perempuan, berusia antara 20 - 30 tahun, latar belakang pendidikan SLTA, dan pekerjaan pegawai swasta dengan penghasilan Rp 2.000.000 - Rp 4.000.000 dan rata-rata pengiriman lebih dari lima kali pengiriman.

Adapun rekapitulasi tanggapan konsumen terhadap bauran pemasaran perusahaan ekspedisi untuk masing-masing variabel dapat di lihat pada tabel berikut:

Tabel 5. Rekapitulasi Skor Variabel Bauran Pemasaran

\begin{tabular}{|c|c|c|c|c|}
\hline No Variabel & Indikator & $\begin{array}{l}\text { Rata-rata } \\
\text { skor }\end{array}$ & Total skor & Keterangan \\
\hline \multirow[t]{2}{*}{1 Produk } & a. Keanekaragaman fitur produk & 4,40 & 4,40 & Sangat beragam \\
\hline & b. Kemanfaatan jasa & 4,40 & & Sangat bermanfaat \\
\hline \multirow[t]{3}{*}{2 Harga } & a. Kesesuaian harga & 4,35 & 4,40 & Sangat sesuai \\
\hline & b. Daya saing harga & 4,45 & & Sangat bersaing \\
\hline & & & & Lanjutan \\
\hline No Variabel & Indikator & $\begin{array}{c}\text { Rata-rata } \\
\text { skor }\end{array}$ & Total skor & Keterangan \\
\hline \multirow[t]{2}{*}{3 Lokasi } & a. Aksesibilitas konsumen & 4,28 & 4,39 & Sangat terjangkau \\
\hline & b. Lokasi strategis & 4,50 & & Sangat strategis \\
\hline \multirow[t]{2}{*}{4 Promosi } & a. Penyampaian informasi & 4,19 & 4,32 & Sangat tersampaikan \\
\hline & $\begin{array}{l}\text { b. Keefektifan penempatan } \\
\text { informasi }\end{array}$ & 4,46 & & Sangat efektif \\
\hline \multirow[t]{2}{*}{5 Orang } & a. Ketanggapan pelayanan & 4,52 & 4,54 & Sangat tanggap \\
\hline & b. Keramahan & 4,56 & & Sangat ramah \\
\hline
\end{tabular}




\begin{tabular}{|c|c|c|c|c|c|}
\hline 6 & Proses & $\begin{array}{l}\text { a. Persyaratan pelayanan } \\
\text { b. Prosedur pelayanan } \\
\text { c. Hasil proses jasa }\end{array}$ & $\begin{array}{l}4,39 \\
4,26 \\
3,92 \\
\end{array}$ & 4,19 & $\begin{array}{l}\text { Mudah } \\
\text { Simple } \\
\text { Puas }\end{array}$ \\
\hline 7 & $\begin{array}{l}\text { Layanan } \\
\text { Pelanggan }\end{array}$ & $\begin{array}{l}\text { a. Jaminan produk } \\
\text { b. Respon komplain }\end{array}$ & $\begin{array}{l}4,38 \\
4,56\end{array}$ & 4,47 & $\begin{array}{l}\text { Sangat terjamin } \\
\text { Sangat baik }\end{array}$ \\
\hline & & Rata-rata & 4,39 & \multicolumn{2}{|c|}{$\begin{array}{l}\text { Sangat beragam, bermanfaat, sesuai, } \\
\text { bersaing, terjangkau, strategis, tersampaikan, } \\
\text { efektif, tanggap, ramah, mudah, simple, puas, } \\
\text { terjamin, baik }\end{array}$} \\
\hline
\end{tabular}

Berdasarkan tabel tersebut rekapitulasi rata-rata bauran pemasaran di PT JNE Agen 012 Citeureup Kabupaten Bogor adalah sebesar 4,39 dengan interprestasi bauran pemasaran pada PT JNE Agen 012 Citeureup Kabupaten Bogor sangat baik.

\section{Hasil Estimasi Persamaan Regresi}

Bentuk persamaan dihitung menggunakan analisis regresi berganda, adapun ringkasan data hasil penelitian disajikan pada tabel sebagai berikut :

Tabel 6. Rangkuman Hasil Perhitungan Analisis Regresi Berganda Model Penelitian

\begin{tabular}{|c|c|c|c|c|}
\hline & & & & \\
\hline $\begin{array}{c}\text { Variabel } \\
\text { (Constant) }\end{array}$ & ${ }^{B}$ & $\begin{array}{r}\text { t hitung } \\
, 393\end{array}$ & $\begin{array}{l}\text { Sig t } \\
\quad 695\end{array}$ & Beta \\
\hline Produk $\left(\mathrm{X}_{1}\right)$ &, 340 & 2,721 & ,008 &, 155 \\
\hline Harga $\left(X_{2}\right)$ & ,358 & 2,423 & ,017 & ,153 \\
\hline Lokasi $\left(\mathrm{X}_{3}\right)$ & 368 & 2,561 & ,012 & , 169 \\
\hline Promosi $\left(\mathrm{X}_{4}\right)$ & ,474 & 2,572 & ,012 & , 195 \\
\hline Orang $\left(\mathrm{X}_{5}\right)$ & ,341 & 2,874 & ,005 & , 175 \\
\hline Proses $\left(\mathrm{X}_{6}\right)$ & 219 & 2,309 & ,023 & , 163 \\
\hline Layanan Pelanggan $\left(\mathrm{X}_{7}\right)$ & 311 & 2,670 & 009 &, 125 \\
\hline \multicolumn{5}{|l|}{ Keputusan Konsumen (Y) } \\
\hline t-tabel & 1,661 & F-hitung & 82,263 & \\
\hline $\mathrm{R}$ &, $929^{\mathrm{a}}$ & F-tabel & 2,11 & \\
\hline R Square &, 862 & Sig F &, $000^{\mathrm{b}}$ & \\
\hline
\end{tabular}

Sumber : Data Diolah (2018)

Berdasarkan tabel tersebut maka dapat dijelaskan bahwa persamaan regresi variabel produk, harga, lokasi, promosi, orang, proses dan layanan pelanggan berpengaruh positif terhadap keputusan konsumen pada perusahaan ekspedisi PT Jalur Nugraha Ekakurir (JNE). Apabila variabel produk, harga, lokasi, promosi, orang, proses dan layanan pelanggan meningkat maka keputusan pembelian juga akan meningkat dan apabila variabel produk, harga, lokasi, promosi, orang, proses dan layanan pelanggan mengalami penurunan maka keputusan konsumen juga akan menurun.

Diketahui bahwa nilai $\mathrm{R}$ sebesar 0,929 termasuk katagori sangat kuat $\quad(0,8-1,000)$ artinya hubungan antara bauran pemasaran (produk, harga, lokasi, promosi, proses, orang dan layanan pelanggan) terhadap keputusan konsumen sangat kuat. Hal tersebut dapat diartikan bahwa perubahan variabel bauran pemasaran akan diikuti oleh perubahan variabel keputusan konsumen, apabila bauran pemasaran meningkat maka keputusan konsumen akan ikut meningkat akan tetapi apabila bauran pemasaran menurun maka keputusan konsumen akan ikut menurun. Besarnya sumbangan variabel bauran pemasaran terhadap keputusan konsumen secara simultan yang dapat dilihat dari $R$ Square sebesar 0,862 yang artinya keputusan konsumen $86,2 \%$ dijelaskan oleh 
bauran pemasaran dan 13,8\% dipengaruhi oleh variabel lain yang tidak diteliti dalam penelitian ini, seperti physical evidence.

Berdasarkan Tabel 5 dijelaskan pula

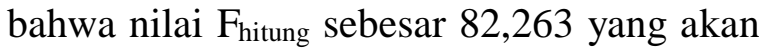
dibandingkan dengan $\mathrm{F}_{\text {tabel, }}$, untuk mengetahui $\mathrm{F}_{\text {tabel }}$ maka perlu perhitungan menggunakan signifikan $\alpha=0,05$ dan derajat kebebasan $(\mathrm{dk}) \mathrm{n}-\mathrm{k}-1$ (100-7-1) = 92 . Dengan melihat hasil dari derajat kebebasan maka didapatkan nilai $F_{\text {tabel }}$ sebesar 2,11 sehingga $F_{\text {hitung }}>F_{\text {tabel }}(27,766>2,11)$ dan memiliki nilai signifikansi $0,000<0,5$ maka Ho ditolak dan Ha diterima, yang artinya dimensi produk, harga, lokasi, promosi, orang, proses dan layanan pelanggan secara simultan berpengaruh positif dan signifikan terhadap keputusan konsumen menggunakan jasa ekspedisi PT JNE Agen 012 CiteureupBogor.

\section{Pengaruh Bauran Pemasaran Terhadap Keputusan Konsumen}

Tabel 7. Rekapitulasi Hasil Uji t

\begin{tabular}{|c|c|c|c|c|}
\hline Variabel & $\mathbf{t}_{\text {hitung }}$ & $\mathbf{t}_{\text {tabel }}$ & Hasil & Kesimpulan \\
\hline Produk & 2,721 & 1,661 & $\begin{array}{l}\mathrm{t}_{\text {hitung }}>\mathrm{t}_{\text {tabel }} \\
\text { Ho ditolak } \\
\text { Ha diterima }\end{array}$ & $\begin{array}{l}\text { Produk berpengaruh positif dan signifikan terhadap } \\
\text { keputusan konsumen menggunakan jasa ekspedisi PT JNE } \\
\text { Agen } 012 \text { Citeureup-Bogor. }\end{array}$ \\
\hline Harga & 2,423 & 1,661 & $\begin{array}{l}\mathrm{t}_{\text {hitung }}>\mathrm{t}_{\text {tabel }} \\
\text { Ho ditolak } \\
\text { Ha diterima }\end{array}$ & $\begin{array}{l}\text { Harga berpengaruh positif dan signifikan terhadap } \\
\text { keputusan konsumen menggunakan jasa ekspedisi PT JNE } \\
\text { Agen } 012 \text { Citeureup-Bogor. }\end{array}$ \\
\hline Lokasi & 2,561 & 1,661 & $\begin{array}{l}\mathrm{t}_{\text {hitung }}>\mathrm{t}_{\text {tabel }} \\
\text { Ho ditolak } \\
\text { Ha diterima }\end{array}$ & $\begin{array}{l}\text { Lokasi berpengaruh positif dan signifikan terhadap } \\
\text { keputusan konsumen menggunakan jasa ekspedisi PT JNE } \\
\text { Agen } 012 \text { Citeureup-Bogor. }\end{array}$ \\
\hline Promosi & 2,572 & 1,661 & $\begin{array}{l}\mathrm{t}_{\text {hitung }}>\mathrm{t}_{\text {tabel }} \\
\text { Ho ditolak } \\
\text { Ha diterima }\end{array}$ & $\begin{array}{l}\text { Promosi berpengaruh positif dan signifikan terhadap } \\
\text { keputusan konsumen menggunakan jasa ekspedisi PT JNE } \\
\text { Agen } 012 \text { Citeureup-Bogor. }\end{array}$ \\
\hline Orang & 2,874 & 1,661 & $\begin{array}{l}\mathrm{t}_{\text {hitung }}>\mathrm{t}_{\text {tabel }} \\
\text { Ho ditolak } \\
\text { Ha diterima }\end{array}$ & $\begin{array}{l}\text { Orang berpengaruh positif dan signifikan terhadap } \\
\text { keputusan konsumen menggunakan jasa ekspedisi PT JNE } \\
\text { Agen } 012 \text { Citeureup-Bogor. }\end{array}$ \\
\hline Proses & 2,309 & 1,661 & $\begin{array}{l}\mathrm{t}_{\text {hitung }}>\mathrm{t}_{\text {tabel }} \\
\text { Ho ditolak } \\
\text { Ha diterima }\end{array}$ & $\begin{array}{l}\text { Proses berpengaruh positif dan signifikan terhadap } \\
\text { keputusan konsumen menggunakan jasa ekspedisi PT JNE } \\
\text { Agen 012 Citeureup-Bogor. }\end{array}$ \\
\hline $\begin{array}{l}\text { Layanan } \\
\text { Pelanggan }\end{array}$ & 2,670 & 1,661 & $\begin{array}{l}\mathrm{t}_{\text {hitung }}>\mathrm{t}_{\text {tabel }} \\
\text { Ho ditolak } \\
\text { Ha diterima }\end{array}$ & $\begin{array}{l}\text { Layanan pelanggan berpengaruh positif dan signifikan } \\
\text { terhadap keputusan konsumen menggunakan jasa } \\
\text { ekspedisi PT JNE Agen } 012 \text { Citeureup-Bogor. }\end{array}$ \\
\hline
\end{tabular}

Sumber : Data kuesioner (diolah) 2018

Berdasarkan Tabel 7 rekapitulasi hasil uji t menunjukkan bahwa produk, harga, lokasi, promosi, orang, proses dan layanan pelanggan secara parsial berpengaruh secara positif dan signifikan terhadap keputusan konsumen menggunakan jasa ekspedisi PT JNE Agen 012 Citeureup Kabupaten Bogor.

\section{KESIMPULAN DAN IMPLIKASI}

Berdasarkan uraian dari bab-bab sebelumnya pada penelitian pengaruh bauran pemasaran terhadap keputusan konsumen perusahaan jasa ekspedisi pada PT JNE Agen 012 Citeureup Kabupaten Bogor. Konsumen yang mewakili populasi dalam penelitian ini berjumlah 100 orang yang diketahui telah menggunakan jasa ekspedisi PT JNE Agen 012 Citeureup Kabupaten Bogor. Sehingga penulis dapat menarik kesimpulan untuk menjawab rumusan masalah sebagai berikut :

1. Konsumen memberikan respon yang positif terhadap bauran pemasaran dan keputusan konsumen pada PT JNE Agen 012 Citeureup Kabupaten Bogor, sehingga dapat disimpulkan kondisi bauran pemasaran pada PT JNE Agen 
012 Citeureup Kabupaten Bogor tergolong pada kategori sangat baik.

2. Berdasarkan hasil uji $F$ diketahui bahwa variabel produk, harga, lokasi, promosi, orang, proses, dan layanan pelanggan secara simultan (bersamasama) mempunyai pengaruh positif dan signifikan terhadap keputusan konsumen menggunakan jasa ekspedisi PT JNE Agen 012 Citeureup-Bogor.

3. Berdasarkan hasil uji $t$ diketahui bahwa variabel produk, harga, lokasi, promosi, orang, proses, dan layanan pelanggan secara parsial mempunyai pengaruh positif dan signifikan terhadap keputusan konsumen menggunakan jasa ekspedisi PT JNE Agen 012 CiteureupBogor.

Berdasarkan hasil penelitian, penulis hendak mengajukan beberapa masukan sebagai bahan pertimbangan bagi perusahaan yang diteliti. Adapun saran-saran yang dapat disampaikan seperti berikut :

1. Hasil penelitian menunjukkan bauran pemasaran berpengaruh tehadap keputusan konsumen dengan kategori sangat baik sehingga dapat disimpulkan penurunan ketercapaian target diduga dipengaruhi oleh faktor lain salah satunya yaitu physical evidence (bukti fisik)

2. Pada bauran pemasaran diketahui proses merupakan pengaruh terendah dalam mempengaruhi keputusan konsumen, diharapkan PT JNE Agen 012 Citeureup Kabupaten Bogor terus meningkatkan kualitas pelayanan produk, harga lokasi, promosi, orang, maupun layanan pelangan khususnya pada proses pelayanan, untuk membantu meningkatkan penggunaan jasa ekspedisi sehingga banyak konsumen yang datang untuk mengirim paket dan hal tersebut akan mempengaruhi omset penjualan yang mengakibatkan perusahaan dapat terus bersaing dan berkembang dengan perusahaan ekspedisi sejenis.
Penulis mengucapkan terimakasih kepada PT Jalur Nugraha Ekakurir (JNE) dan Universitas Djuanda Bogor

\section{DAFTAR PUSTAKA}

Alma, Buchari. 2014 . Manajemen Pemasaran dan Pemasaran Jasa. Alfabeta. Bandung.

Lupiyoadi, Rambat. 2014. Manajemen Pemasaran Jasa, Edisi 3. Jakarta. Salemba Empat.

Mc Daniel, Carl dan Rogers Gates, Riset Pemasaran Kontemporer. Salemba empat. Jakarta.

Sara, Muhamad Taufiq. 2013. Pengaruh Bauran Pemasaran Jasa Terhadap. Keputusan Pembelian Jasa Pengiriman Barang Pada PT JNE Di Bandar Lampung. Skripsi. Universitas Lampung. Bandar Lampung.

Sugiyono. 2010. Metode Penelitian Kuantitatif, Kualitatif, dan $R \& D$. Alfabeta. Bandung.

Sugiyono. 2016. Metode Penelitian Kuantitatif, Kualitatif, dan $R \& D$, Cetakan 23. Alfabeta. Bandung.

Sujarweni, Wiratno. 2015. Metodologi Penelitian "Bisnis dan Ekonomi", Cetakan 1. Pustaka Baru Press. Yogyakarta.

Sumarwan, Ujang dkk. 2012. Riset Pemasaran dan Konsumen Seri 2. Cetakan 1. IPB Press. Bogor.

Thamrin, Abdullah dan Francis Tantri. 2016. Manajemen Pemasaran, Edisi 1 Cetakan 5. Rajawali Pers. Jakarta.

Tjiptono, Fandy. 2014. Pemasaran Jasa "Prinsip, Penerapan, dan Penelitian", Edisi 1. CV Andi Offset. Yogyakarta. Tjiptono, Fandy. 2016. Pemasaran "Esensi dan Aplikasi”, Edisi 1. CV Andi Offset. Yogyakarta.

http://www.jne.co.id diakses pada 26 November 2017 pukul 13:00

Republik Indonesia. 2009. Undang-undang No. 38 Tahun 2009 tentang Pos.

\section{UCAPAN TERIMAKASIH}

